\title{
Size, growth, and origin-dependent mortality of juvenile Chinook salmon Oncorhynchus tshawytscha during early ocean residence
}

\author{
Lindsay E. Woodson ${ }^{1, *}$, Brian K. Wells ${ }^{1}$, Peter K. Weber $^{2}$, R. Bruce MacFarlane ${ }^{1}$, \\ George E. Whitman ${ }^{3}$, Rachel C. Johnson ${ }^{3,4}$
}

${ }^{1}$ Fisheries Ecology Division, Southwest Fisheries Science Center, National Marine Fisheries Service, National Oceanic and Atmospheric Administration, 110 Shaffer Road, Santa Cruz, California 95060, USA

${ }^{2}$ Chemical Sciences, Lawrence Livermore National Laboratory, Livermore, California 94551

${ }^{3}$ Institute of Marine Sciences, University of California Santa Cruz, Santa Cruz, California 95064, USA

${ }^{4}$ US Bureau of Reclamation, Bay-Delta Office, Sacramento, California 95825, USA

\begin{abstract}
Selective mortality during early life history stages can have significant populationlevel consequences, yet critical periods when selective mortality occurs, the strength of selection, and under what environmental conditions can be difficult to identify. Here, we used otolith microstructure and chemistry to examine the factors potentially linked to selective mortality of juvenile fall-run Chinook salmon Oncorhynchus tshawytscha from California's Central Valley during early ocean residence. Back-calculated size and growth rates of the population were compared across 3 sample periods: as juveniles exited the San Francisco Bay estuary (estuary-exit), after their first month at sea (summer-ocean) and 5 mo after ocean entry (fall-ocean). We compared mortality dynamics during years of exceptional recruitment (addition of individuals to harvestable population; 2000 and 2001) to a year of poor recruitment (2005). Otoliths from 2005 were also analyzed for sulfur isotopes to discern hatchery from naturally spawned stock. Significant size and growth-rate selective mortality were detected during the first month at sea in the low recruitment year of 2005, but not in 2000 and 2001. Individuals that were larger and growing faster during freshwater and estuarine rearing were more likely to survive to summer and fall in the low recruitment year. There was a slight, but insignificant, increase in the proportion of hatchery to naturally spawned individuals from estuary-exit to fall-ocean, suggesting that fish from neither origin were overwhelmingly favored. Our results suggest that Central Valley Chinook salmon can be subject to significant size and growth-rate selective mortality resulting in low adult abundance, and this mortality appears independent of origin.
\end{abstract}

KEY WORDS: Critical period · Otolith $\cdot$ California Current $\cdot$ Hatchery $\cdot$ Gulf of the Farralones

Resale or republication not permitted without written consent of the publisher

\section{INTRODUCTION}

Fish populations typically experience their highest mortality rates during the early life-history stages (Anderson 1988, Pearcy 1992, Sogard 1997). In many salmonid species the transition from the estuarine to ocean environment as juveniles is considered a critical period of high mortality (Parker 1968, Pearcy
1992, Beamish \& Mahnken 2001, Wells et al. 2012). This mortality can be non-random, with the smaller, slower-growing individuals lost to predation or starvation (Parker 1971, Shepherd \& Cushing 1980, Miller et al. 1988). Understanding the factors responsible for selective mortality and its timing is critical for accurate estimates of recruitment (addition of individuals to a harvestable population) and year- 
class strength (Hjort 1914, Gulland 1965, Houde 1987, Crowder et al. 1992). Changes in the distribution of population traits (e.g. body size) during early life-history stages can provide insight into selective mortality processes. If we can identify and measure the traits associated with survival, we may be able to better anticipate the success or failure of particular cohorts and consider harvest management actions relevant to all cohorts in the stock (Crowder et al. 1992).

Empirical data quantifying the mechanism and timing of selective mortality are often difficult to obtain. Fish otoliths present an opportunity to address these questions by allowing retrospective analysis of size and growth distributions of the population. Otoliths are calcified structures that grow by accreting permanent layers of calcium carbonate and protein (Campana \& Neilson 1985). The otolith radius is significantly related to fish body size (e.g. fork length), and daily increments record growth rate, with larger increments accumulating in periods of faster growth (Neilson \& Geen 1982, Campana \& Neilson 1985, Bradford \& Geen 1987, Campana 1990, Titus et al. 2004). Otoliths, therefore, allow us to back-calculate the body sizes and growth rates of surviving members of a population, and compare them to those previously sampled from the same population. A shift in the distribution of these traits may indicate selective mortality, and the timing of the shift may indicate when in the life history the selective mortality occurred (Grimes \& Isely 1996).

Differences in juvenile salmon body size and growth rates also vary as a function of their rearing origin (Barnett-Johnson et al. 2007). Hatchery salmon generally grow faster and reach a larger size at release, which may increase the survival rates of hatchery individuals compared with those of natural origin (Unwin 1997, Reinhardt et al. 2001). Production hatcheries release a significant number of unmarked salmon in many regions, therefore there is great interest in understanding whether selective mortality processes in years of poor overall survival bias the population composition towards hatchery-origin fish. Specifically, there is evidence that the presence of hatchery fish reduces the marine survival of naturally spawned individuals, probably due to competition and their larger body size (Levin et al. 2001, Ruggerone et al. 2010). Conversely, decreased survival rates have also been shown in hatchery fish as a result of asynchronous release timing with peak prey abundance and marine productivity (Beamish et al. 2008, 2012), as well as due to domestication (Fritts et al. 2007).
In 2007, California's Central Valley fall-run Chinook salmon Oncorhynchus tshawytscha population of returning adults was at an historic low (Lindley et al. 2009) resulting in a closure of the fisheries in 2008 and 2009. Poor marine survival of juveniles that entered the ocean in 2005 was thought to have contributed to this collapse (Lindley et al. 2009). In general, it was observed that in the spring of 2005 juveniles were not unlike those in more successful cohorts, such as years 2000 and 2001, with regards to body size and lipid content on estuary-exit. However, by their first month at sea, juveniles from 2005 were smaller and had lower lipid concentrations, which implicates factors in the ocean as driving differences in mortality across years (Fig. 1; data from MacFarlane 2010). In the central California coastal system, upwelling dynamics were similar during the spring of 2000 and 2001, and were characterized by produc-
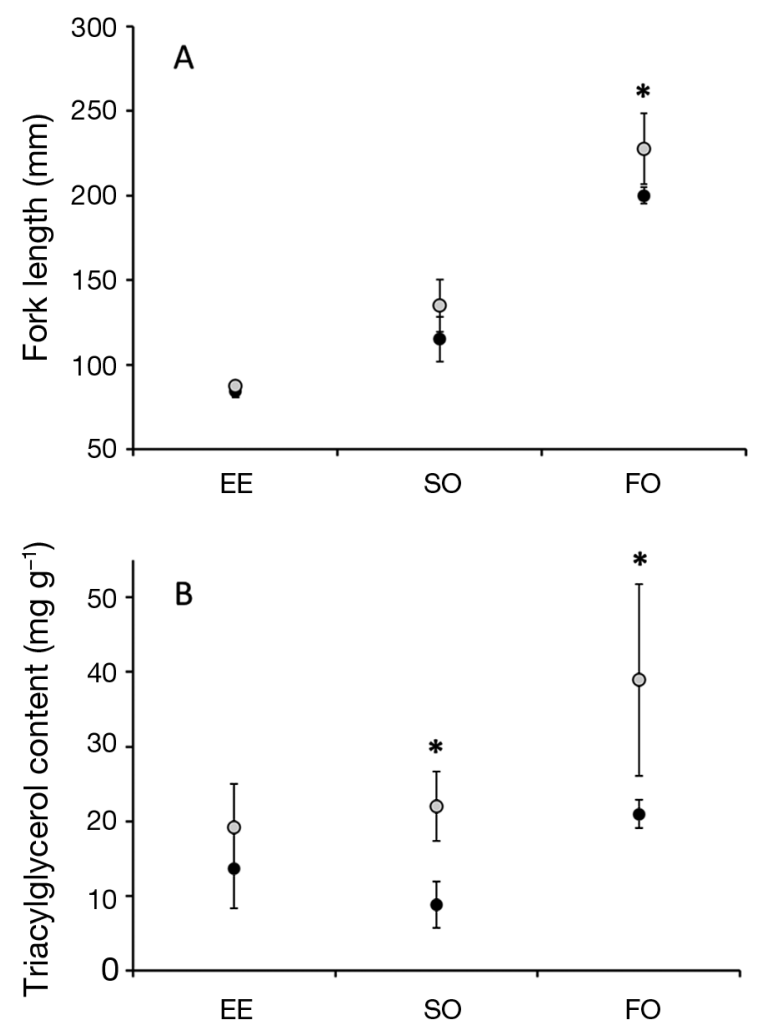

Fig. 1. Means and $95 \%$ confidence intervals of (A) measured fork length (mm) and (B) measured triacylglycerol content $\left(\mathrm{mg} \mathrm{g}^{-1}\right)$ at capture across 3 sample periods: estuary-exit (EE), summer-ocean (SO), and fall-ocean (FO). In both cases, fish from 2005 (black) were significantly smaller and lower in lipid content than fish from 2000 and 2001 (grey) by fallocean. Stars denote significant differences (ANOVA) with $\mathrm{p}<0.001$. Data from MacFarlane (2010) 
tive conditions with normal to high abundances of zooplankton and forage fish (Durazo et al. 2001, Schwing et al. 2002). In contrast, the late onset of upwelling in 2005 resulted in anomalously low abundances of salmon prey items during the time period when juvenile Chinook salmon were entering the ocean (Peterson et al. 2006, Schwing et al. 2006, Barth et al. 2007, Lindley et al. 2009), which relates directly to the ultimate condition and later abundance of Central Valley Chinook salmon (Wells et al. 2012). Subsequently the subyearling cohorts of 2000 and 2001 recruited as adults in high numbers, unlike the subyearlings from 2005.

Here, we used otolith microstructure and chemistry to evaluate the factors linked to potential selective mortality of juvenile fall-run Chinook salmon from California's Central Valley during contrasting years of recruitment. Retrospective changes in the frequency distributions of body sizes, growth rates, and proportion of hatchery-born individuals in the population were assessed across 3 time periods within the critical early ocean period: first as they exited the San Francisco Bay estuary (estuary-exit), again 1 mo after ocean entry (summer-ocean), and approximately 5 mo after ocean entry (fall-ocean).

High rates of mortality on smaller, slower-growing individuals following ocean entry has been previously documented in other species and stocks of juvenile salmon using mark-recapture techniques (Parker 1968, Bilton et al. 1982, Bax 1983, Duffy \& Beauchamp 2011), back-calculated size and growth estimates with scales (Healey 1982, Ward et al. 1989, Holtby et al. 1990, Cross et al. 2008), and otoliths (Neilson \& Geen 1986, Good et al. 2001). Despite previous studies of this kind on other salmonid species and stocks, no similar work has been done for California's Central Valley Chinook salmon-the overwhelming contributor to the commercial and recreational salmon fisheries off California. Importantly, California's Central Valley Chinook salmon originate from the extreme southern end of the species distribution (MacFarlane \& Norton 2002), suggesting that previous studies on populations more centrally or northerly distributed may not suffice to capture the dynamics of this population. In addition, unlike most previous studies, our sampling design explicitly captured the period of ocean entry by sampling the population as it exited the estuary, thus enabling us to evaluate selective mortality at the earliest time at sea. This study is also unique in that we used an innovative approach to evaluate the extent to which hatchery versus natural rearing influences selective mortality.
We tested for evidence of selective mortality on juvenile fall-run Chinook salmon from California's Central Valley in years of contrasting recruitment (exceptionally high versus exceptionally low). We hypothesized that, if present, selective mortality would be greater during 2005 than during the more productive ocean years of 2000 and 2001, and that survivorship may be influenced by rearing origin.

\section{MATERIALS AND METHODS}

\section{Sample collection}

Subyearling Chinook salmon were collected as part of an annual trawl survey conducted by the National Oceanic and Atmospheric Administration Southwest Fisheries Science Center. These surveys sampled subyearling Chinook salmon spatially and temporally over their early ocean residence. The subyearling population was first sampled beneath the Golden Gate Bridge in May and June as it exited the estuary (estuary-exit; Fig. 2). A broader range of stations in the coastal ocean were sampled during June and July (summer-ocean) and again during October (fall-ocean) (Fig. 2). These sampling periods coincided with the documented juvenile emigration timing of California's Central Valley fall-run Chinook

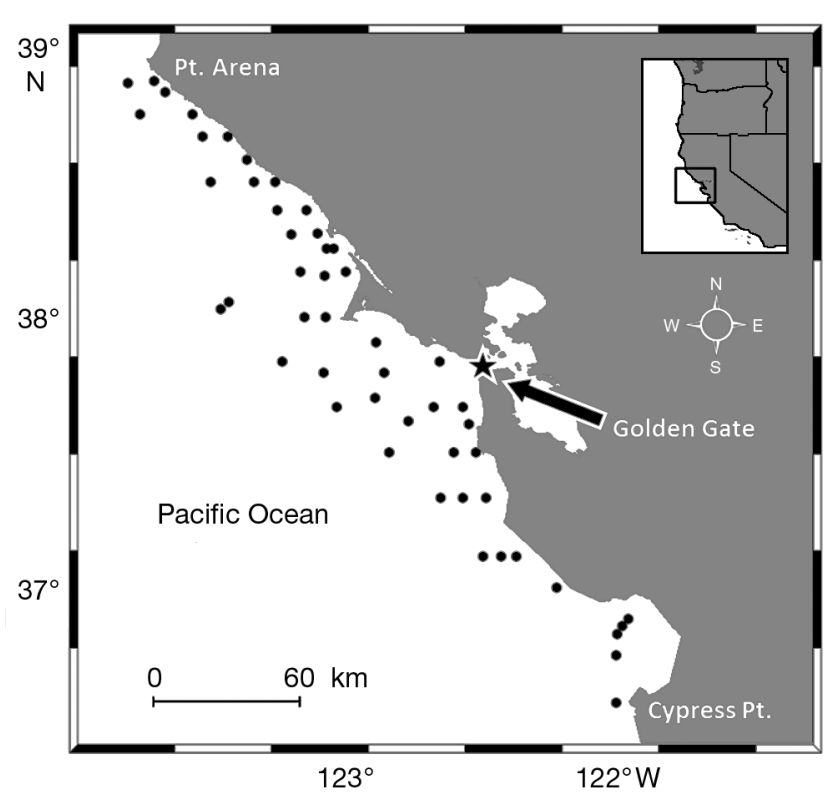

Fig. 2. Sampling locations. Estuary-exit trawls were conducted beneath the Golden Gate Bridge (star). Coastal ocean stations were sampled during summer- and fall-ocean sample periods 
Table 1. Sampling dates and available sample sizes for each year of interest at estuary-exit (EE), summer-ocean (SO), and fall-ocean (FO). Sample sizes do not reflect abundance

\begin{tabular}{|lllllll|}
\hline Year & EE & N & SO & N & FO & N \\
\hline 2000 & $\begin{array}{l}\text { May 17-18, 23-24 } \\
\text { Jun 5-6 } \\
\text { May 22-23 }\end{array}$ & 35 & Jun 20-30 & 32 & $\begin{array}{l}\text { Sep 26-29 } \\
\text { Oct 2-6 }\end{array}$ & 2 \\
2001 & 35 & Jul 24-Aug 5 & 25 & Oct 19-26 & 10 \\
Jun 12-13 & $\begin{array}{l}\text { May 10-11 } \\
\text { Jun 7-8 }\end{array}$ & 84 & Jun 18-25 & 87 & Oct 5-13 & 80 \\
\hline
\end{tabular}

Further detail of the estuary-exit trawling process can be found in MacFarlane et al. (2005).

Coastal ocean stations (summerand fall-ocean) were located between Point Arena, California $\left(38^{\circ} 55^{\prime} \mathrm{N}\right.$, $\left.123^{\circ} 44^{\prime} \mathrm{W}\right)$ and Cypress Point, California $\left(36^{\circ} 34.5^{\prime} \mathrm{N}, 122^{\circ} 00^{\prime} \mathrm{W}\right)$ (Fig. 2). The coastal stations were sampled with a Nordic 264 rope trawl towed at the surface for 6 to $40 \mathrm{~min}$ (average $22 \mathrm{~min}$ ) at a speed of 3 to 4 knots. The net was $27 \mathrm{~m}$ wide and $194 \mathrm{~m}$ long,

salmon (Fisher 1994) and allowed us to track changes in the population over the critical period of early ocean residence. We focused on 3 years of sampling from this annual survey that captured differing ocean conditions and overall recruitment (Table 1). Years 2000 and 2001, combined to increase sample size, were years of productive ocean conditions (Durazo et al. 2001, Schwing et al. 2002) that resulted in similarly exceptional adult abundance 2 yr later (second and fourth greatest adult abundances on record; Pacific Fisheries Management Council 2013). Otolith data from 2000 and 2001 were part of an historical data set, and few physical otoliths were available to us. The springs and summers of 2000 and 2001 represented similar ocean conditions and high salmon recruitment to adulthood, therefore, while not ideal, we felt there was sufficient support that combining the otolith data between these collections would not bias our study results. Year 2005 was a year of poor ocean conditions and resulted in low adult abundance in the ocean and historically low returns to the river in 2007 (Lindley et al. 2009). This was not a study to compare the specific oceanic conditions that lead to potential selective morality but, rather, to simply evaluate whether contrasting years of recruitment could have resulted, in part, from selective forces. However, as 2000 and 2001 also represented generally productive conditions and 2005 did not, we have the opportunity to qualitatively evaluate the impact of environmental conditions on mortality dynamics.

The estuary-exit station was located beneath the Golden Gate Bridge in San Francisco, California (Fig. 2) and was sampled with a midwater trawl towed at the surface for durations of 15 to $30 \mathrm{~min}$ at speeds of 2 to 3 knots. The net was $20 \mathrm{~m}$ long with $10 \mathrm{~m}$ head and foot ropes, and sampled the top $10 \mathrm{~m}$ of water. The nylon mesh had a gradient of $1.6 \mathrm{~cm}$ at the head rope to $0.4 \mathrm{~cm}$ at the codend. The codend itself was fitted with a $1.27 \mathrm{~cm}$ knotless mesh liner. and sampled the top $14 \mathrm{~m}$ of water. The mesh gradient ranged from 163 to $9 \mathrm{~cm}$ in the codend. The codend liner was $6 \times 10 \mathrm{~mm}$ knotless nylon. Further detail of the coastal ocean trawling process can be found in MacFarlane (2010).

\section{Sample preparation and analysis}

All fish were measured, weighed, and then kept frozen or under ice until their otoliths were removed. After removal, otoliths were rinsed with deionized water and cleaned of adhering tissue. Dry otoliths were stored in microcentrifuge tubes until they were prepared for increment analysis. Otoliths were mounted in Crystalbond ${ }^{\mathrm{TM}}$ resin and polished using a succession of lapping films (600 grit, 1500 grit, 3 um and $1 \mu \mathrm{m}$ ) until the primordia were exposed and daily increments were clearly visible.

Daily otolith increments were counted and measured along standardized transects from the postrostrum primordia in the dorsal direction (Fig. 3). Daily increment measurements began at the exogenous feeding check (Marshall \& Parker 1982) and continued to the outer edge. Otoliths from 2000 and 2001 were archived samples previously measured along the $30^{\circ}$ transect. More recently, the $90^{\circ}$ transect has become the accepted standard assessment practice for Chinook salmon otoliths across multiple labs (Titus et al. 2004), and otolith samples from 2005 were measured along the $90^{\circ}$ transect. Unfortunately the archived samples were prepared to maximize readability along the $30^{\circ}$ transect, leaving very few samples that could be re-read along the $90^{\circ}$ transect. It is important to note that the increment widths between the 2 transects, and in our case years, are not directly comparable due to the shape of the otolith; increments along the $30^{\circ}$ transect will always be larger than those along the $90^{\circ}$ transect. 


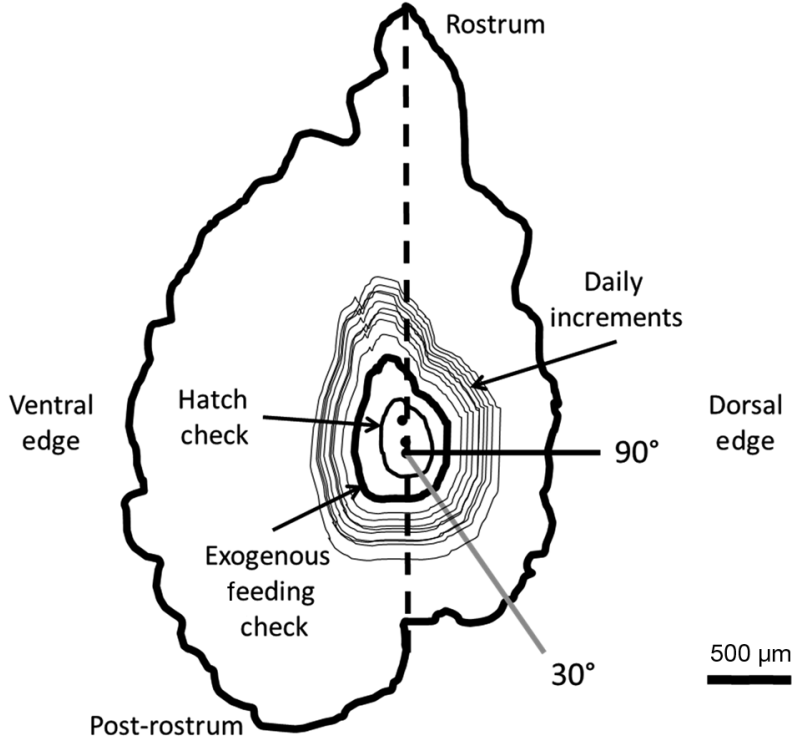

Fig. 3. Increment measurement transects differed between years. Otoliths from 2000 and 2001 were measured along the $30^{\circ}$ transect. Otoliths from 2005 were measured along the $90^{\circ}$ transect. Transects originated at the primorida closest to the post-rostrum and were oriented in the dorsal direction. Measurements began at the exogenous feeding check and continued to the outer edge. Daily increments were measured and counted

For juvenile Chinook salmon, a strong relationship exists between otolith radius and fork length (Neilson \& Geen 1982, Bradford \& Geen 1987, Titus et al. 2004). To make the data both comparable between years and maintain adequate sample size, back-cal- culated otolith radii $(\mu \mathrm{m})$ and increment widths $\left(\mu \mathrm{m} \mathrm{d}^{-1}\right)$ were converted to fork length $(\mathrm{mm})$ and growth rates $\left(\mathrm{mm} \mathrm{d}^{-1}\right)$. These conversions were done using otolith radius to fork length regressions defined for each transect type (Fig. 4). To confirm that both the $30^{\circ}$ and $90^{\circ}$ transect measurements appropriately represented fork length, a subset of readable otoliths that had been previously read along the $30^{\circ}$ transect were re-read along the $90^{\circ}$ to compare the 2 transects. Actual fork lengths at capture were regressed against the calculated fork lengths from the $30^{\circ}$ transect conversion and had a good linear fit $\left(\mathrm{N}=58, \mathrm{R}^{2}=0.83, \mathrm{p}<0.001\right)$. The same was done for the $90^{\circ}$ transect subset, which also had a good linear fit $\left(\mathrm{N}=58, \mathrm{R}^{2}=0.82, \mathrm{p}<0.001\right)$. A regression between the fork lengths calculated from the $30^{\circ}$ and $90^{\circ}$ transects for the same fish showed good linear agreement $\left(\mathrm{N}=58, \mathrm{R}^{2}=0.79, \mathrm{p}<0.001\right)$. In all 3 cases, residuals were randomly distributed. We are, therefore, confident that both transects may be used to convert to fork length, and after doing so, are comparable.

Owing to differences in diets, hatchery and naturally produced salmon can be distinguished by quantifying the sulfur isotope ratio ${ }^{34} \mathrm{~S} /{ }^{32} \mathrm{~S}$ within the juvenile portion of the otolith (Weber et al. 2002, Johnson et al. 2012). The ${ }^{34} \mathrm{~S} /{ }^{32} \mathrm{~S}$ ratio is expressed in delta notation $\delta^{34} \mathrm{~S}$, where $\delta^{34} \mathrm{~S}=\left[\left({ }^{34} \mathrm{~S} /{ }^{32} \mathrm{~S}\right)_{\text {meas }} /\left({ }^{34} \mathrm{~S} /{ }^{32} \mathrm{~S}\right)_{\mathrm{CDT}}-\right.$ 1] $\times 1000 \%$, $\left({ }^{34} \mathrm{~S} /{ }^{32} \mathrm{~S}\right)$ meas is the measured sulfur isotope ratio and $\left({ }^{34} \mathrm{~S} /{ }^{32} \mathrm{~S}\right)_{\mathrm{CDT}}$ is the Canyon Diablo Troilite reference ratio, 0.044163 (Ding et al. 2001). For the poor recruitment year of 2005, a subset of the
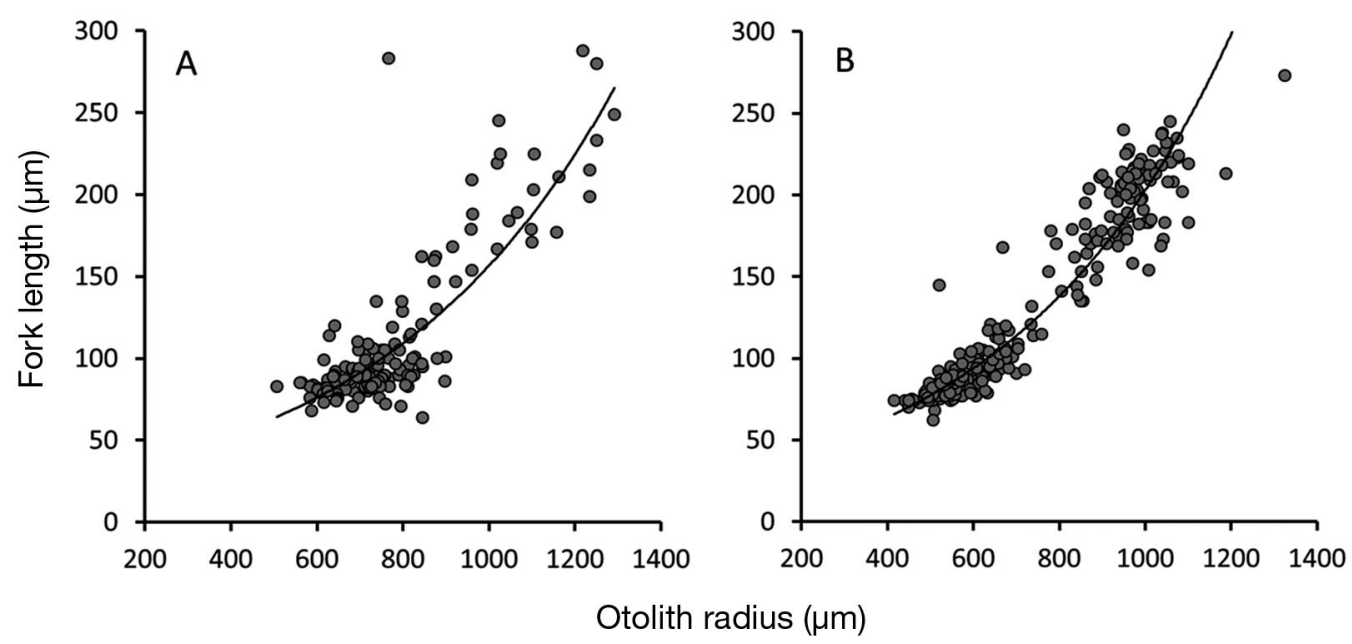

Fig. 4. Regressions between otolith radius and fork length at capture yielded exponential relationships that were used to convert back-calculated otolith radii into fork lengths. Regressions were done within year to account for the different otolith measurement transects: (A) 2000 and 2001, $y=25.76 \mathrm{e}^{0.0018 x}, \mathrm{R}^{2}=0.71$; (B) 2005, $y=29.535 \mathrm{e}^{0.0019 x}, \mathrm{R}^{2}=0.92$ 
otoliths was selected for sulfur isotope analysis. Otoliths were randomly chosen from the estuary-exit ( $N=61)$ and fall-ocean samples $(\mathrm{N}=66)$ to determine whether there was a change in the proportion of hatchery and naturally spawned fish following ocean entry. Otolith sulfur isotopes were measured using an ion microprobe at the University of California at Los Angeles (Cameca IMS 1270, National Ion Microprobe Facility). Techniques are described in Weber et al. (2002) and Johnson et al. (2012). Sulfur isotopes were measured in 3 spots of $\sim 30 \mu \mathrm{m}$ diameter ( 6 to $10 \mathrm{~d}$ of growth) in the core of the otolith and in the portion of the otolith deposited just after yolk absorption but before outmigration (post exogenous feeding, $\mathrm{PEF}$ ). The difference in the mean $\delta^{34} \mathrm{~S}$ between the core and PEF were determined for sample classification (Weber et al. 2002, Johnson et al. 2012). Individuals that had differences in the mean $\delta^{34} \mathrm{~S} \pm$ 1 standard error between the core and PEF of greater than 6.5 were considered to be naturally spawned. The difference in $\delta^{34} \mathrm{~S}$ of 6.5 corresponds to a PEF value of $\sim 8.5 \%$, with fish exhibiting greater PEF values to be hatchery fish receiving isotopically heavier marine protein in their feed (Weber et al. 2002).

\section{Statistical analysis}

For each sample period (estuary-exit, summerocean, and fall-ocean) we back-calculated the average fork length $(\mathrm{mm})$ at given ages (i.e. increments) and means were compared at $10 \mathrm{~d}$ increment steps (e.g. at ages 10, 20, $30 \mathrm{~d}$, etc.). Age categories with fewer than 10 otolith samples were not included in the analysis. Significant differences in mean fork length indicate shifts in the body size at a given age and may indicate size-selective mortality at that age. A repeated-measures ANOVA was used, as increments in otoliths for individual fish are measured over time and are potentially correlated and nonindependent.

In addition to comparing back-calculated size at different ages, we also compared back-calculated size frequency distributions at ocean entry. Using the average age (days post exogenous feeding) at estuary-exit $(2000$ and 2001 mean $=104 \mathrm{~d}, \mathrm{SD}=23 ; 2005$ mean $=93 \mathrm{~d}, \mathrm{SD}=20$ ) as our ocean-entry benchmark, we calculated the fork length at the corresponding age for each fish to construct a size distribution of the population at ocean entry for all 3 sample periods within each year. Changes observed in the oceanentry size distribution between any of the sample periods (estuary-exit, summer-ocean, fall-ocean) would suggest size-selective mortality. Following Claiborne et al. (2011) we used a Wilcoxon rank sum test to compare distributions.

Growth was calculated by subtracting the consecutive back-calculated fork lengths (FL) (e.g. Growth $_{\text {age } x}=\mathrm{FL}_{\text {age } x}-\mathrm{FL}_{\text {age } x-1}$, where 'age $x$ ' is the otolith growth increment sampled). Specific growth rates were then calculated (total growth in $50 \mathrm{~d}$ divided by initial size before that $50 \mathrm{~d}$ period) in overlapping 50 d intervals (i.e. Days 1-50, 25-75, 50-100, etc.), as $50 \mathrm{~d}$ is optimal for resolving differences in growth (Bradford \& Geen 1987). Means were then compared (ANOVA) across the 3 sample periods (estuary-exit, summer-ocean, fall-ocean) for each year. Intervals with fewer than 10 samples were not included in the analysis. Divergence in the mean back-calculated growth rate between sample periods would suggest selection on growth rate. The $50 \mathrm{~d}$ window in which a divergence occurs may indicate the window over which faster growth was important.

In addition to examining size and growth, we explored whether there was selective mortality in the poor survival year of 2005 as a function of whether fish spent their early life in a river or a hatchery. A change in the proportion of hatchery and naturally spawned fish from estuary-exit to fall-ocean (chisquare) may indicate a survival advantage of rearing origin in a poor survival year. To determine the most accurate proportions of hatchery and natural individuals we used Laplace's procedure (Laplace 1812) to produce $95 \%$ confidence intervals (Johnson et al. 2012). The confidence intervals were governed by binomial statistics and were calculated using the adjusted Wald estimate modified for small sample sizes (Lewis \& Sauro 2006, Johnson et al. 2012). This analysis was not done for the 2000 and 2001 samples as these were part of an historical data set and we were limited by the number of physical otoliths available to us.

\section{RESULTS}

\section{Size}

In 2005, significant divergence in back-calculated fork length was observed as early as $60 \mathrm{~d}$ post exogenous feeding (Fig. 5). Tukey's post hoc test revealed that estuary-exit fish were significantly smaller than the survivors in the fall sample had been at age $60 \mathrm{~d}$ (repeated-measures ANOVA, p < 0.05) and significantly smaller than both the summer- and fall-ocean populations at ages 70 to $110 \mathrm{~d}$ (repeated-measures 

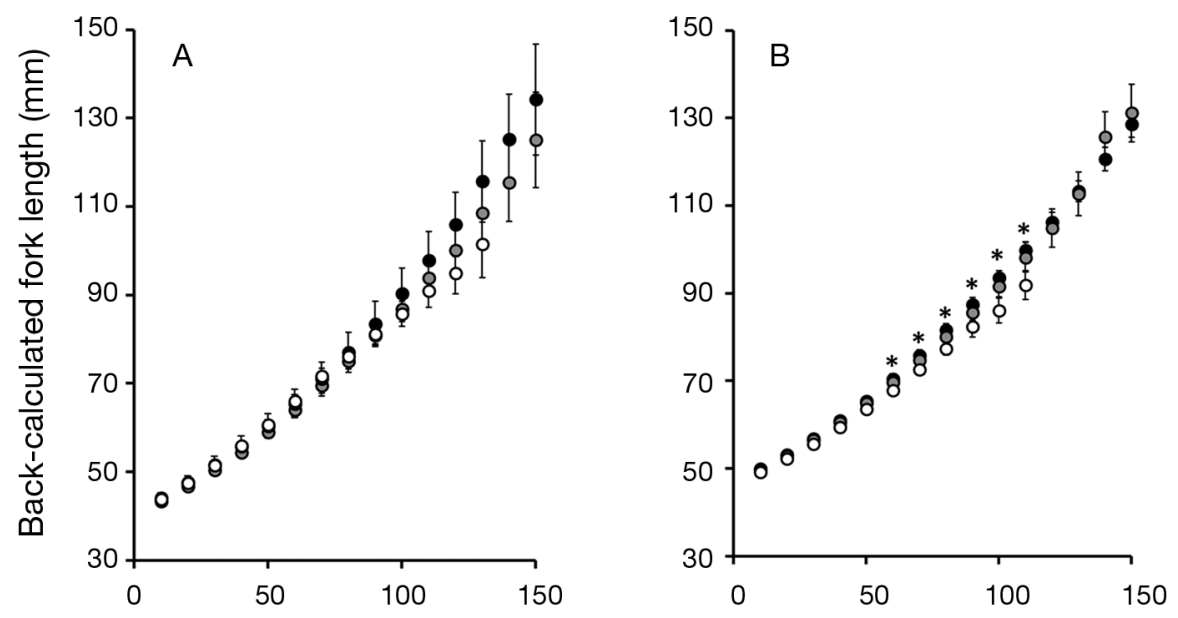

Age post exogenous feeding (d)

Fig. 5. Average back-calculated fork lengths (mm) and $95 \%$ confidence intervals at age post exogenous feeding for estuary-exit (white), summer-ocean (grey), and fall-ocean (black) in (A) 2000 and 2001 and (B) 2005. Stars denote ANOVA significance with $\mathrm{p}<0.05$

ocean during summer and fall exhibited faster retrospective growth relative to the population when sampled at estuary-exit. As with body size in 2005, a Tukey's post hoc test revealed no differences in growth rate between the summer and fall populations. In 2000 and 2001 no significant differences in specific retrospective growth rate were observed between any of the sample periods.

\section{Rearing origin}

Sulfur isotope analysis indicated that at estuary-exit $60 \%$ (confidence interval $=42$ to $72 \%$ ) of our sample was comprised of hatchery fish (hatchery $\mathrm{N}=32$, natural $\mathrm{N}=21$ ). By fall, only a modest increase in the

ANOVA, $\mathrm{p}<0.01)$. Summer and fall samples were not different from each other. There was no difference in back-calculated fork length between any of the sample periods in 2000 and 2001.

In 2005, the back-calculated size distribution at the ocean-entry benchmark of juveniles sampled at estuary-exit was significantly different from juveniles collected in the summer- and fall-ocean periods (Fig. 6; Wilcoxon rank sum test, p < 0.01). The shift in distribution was to the right, suggesting that the larger individuals at ocean entry had a survival advantage in 2005. The backcalculated size distributions at ocean entry of the summer and fall populations were not different. In contrast, in 2000 and 2001 there was no significant shift in the distribution of fork lengths between any of the sample periods at the ocean-entry benchmark.

\section{Growth rate}

In 2005, significant differences in retrospective specific growth rate were detected as early as 1-50 d (ANOVA, $\mathrm{p}=0.046$ ) with the most compelling evidence of selective mortality related to growth rate observed at intervals of 25-75 and 50-100 d (ANOVA, p < 0.001) (Table 2, Fig. 7), which encompass the period of freshwater and estuarine growth before ocean entry. Fish collected in the
Table 2. Mean specific growth rate ANOVA results for each $50 \mathrm{~d}$ window across all 3 sample periods (estuary-exit, EE; summer-ocean, $\mathrm{SO}_{\text {; }}$ fall-ocean, FO) in both 2000 and 2001 and 2005

\begin{tabular}{|c|c|c|c|c|c|c|c|}
\hline \multirow{2}{*}{\multicolumn{2}{|c|}{$\begin{array}{l}\text { Days post exo- } \\
\text { genous check }\end{array}$}} & \multicolumn{3}{|c|}{2000 and 2001} & \multicolumn{3}{|c|}{2005} \\
\hline & & $\mathrm{N}$ & Mean & $\mathrm{SD}$ & $\mathrm{N}$ & Mean & $\mathrm{SD}$ \\
\hline \multirow[t]{4}{*}{$1-50$} & $\mathrm{EE}$ & 70 & 0.491 & 0.09 & 83 & 0.364 & 0.08 \\
\hline & $\mathrm{SO}$ & 57 & 0.467 & 0.09 & 87 & 0.387 & 0.08 \\
\hline & $\mathrm{FO}$ & 12 & 0.482 & 0.09 & 80 & 0.392 & 0.08 \\
\hline & & & $\mathrm{p}=0.31$ & & & $p=0.05$ & \\
\hline \multirow[t]{4}{*}{$25-75$} & $\mathrm{EE}$ & 63 & 0.507 & 0.11 & 75 & 0.396 & 0.06 \\
\hline & $\mathrm{SO}$ & 56 & 0.494 & 0.09 & 85 & 0.422 & 0.08 \\
\hline & $\mathrm{FO}$ & 12 & 0.497 & 0.09 & 80 & 0.440 & 0.08 \\
\hline & & & $\mathrm{p}=0.78$ & & & $p<0.001$ & \\
\hline \multirow[t]{4}{*}{$50-100$} & $\mathrm{EE}$ & 35 & 0.478 & 0.10 & 28 & 0.370 & 0.06 \\
\hline & SO & 46 & 0.479 & 0.08 & 54 & 0.415 & 0.07 \\
\hline & $\mathrm{FO}$ & 12 & 0.502 & 0.08 & 80 & 0.436 & 0.07 \\
\hline & & & $p=0.67$ & & & $p<0.001$ & \\
\hline \multirow[t]{4}{*}{$75-125$} & $\mathrm{EE}$ & 16 & 0.436 & 0.09 & - & - & - \\
\hline & $\mathrm{SO}$ & 24 & 0.455 & 0.08 & 26 & 0.382 & 0.06 \\
\hline & $\mathrm{FO}$ & 11 & 0.505 & 0.06 & 80 & 0.398 & 0.06 \\
\hline & & & $\mathrm{p}=0.08$ & & & $\mathrm{p}=0.06$ & \\
\hline \multirow[t]{4}{*}{$100-150$} & $\mathrm{EE}$ & - & - & - & - & - & - \\
\hline & $\mathrm{SO}$ & 17 & 0.444 & 0.09 & 13 & 0.372 & 0.05 \\
\hline & $\mathrm{FO}$ & 10 & 0.492 & 0.06 & 80 & 0.379 & 0.05 \\
\hline & & & $\mathrm{p}=0.31$ & & & $\mathrm{p}=0.22$ & \\
\hline
\end{tabular}




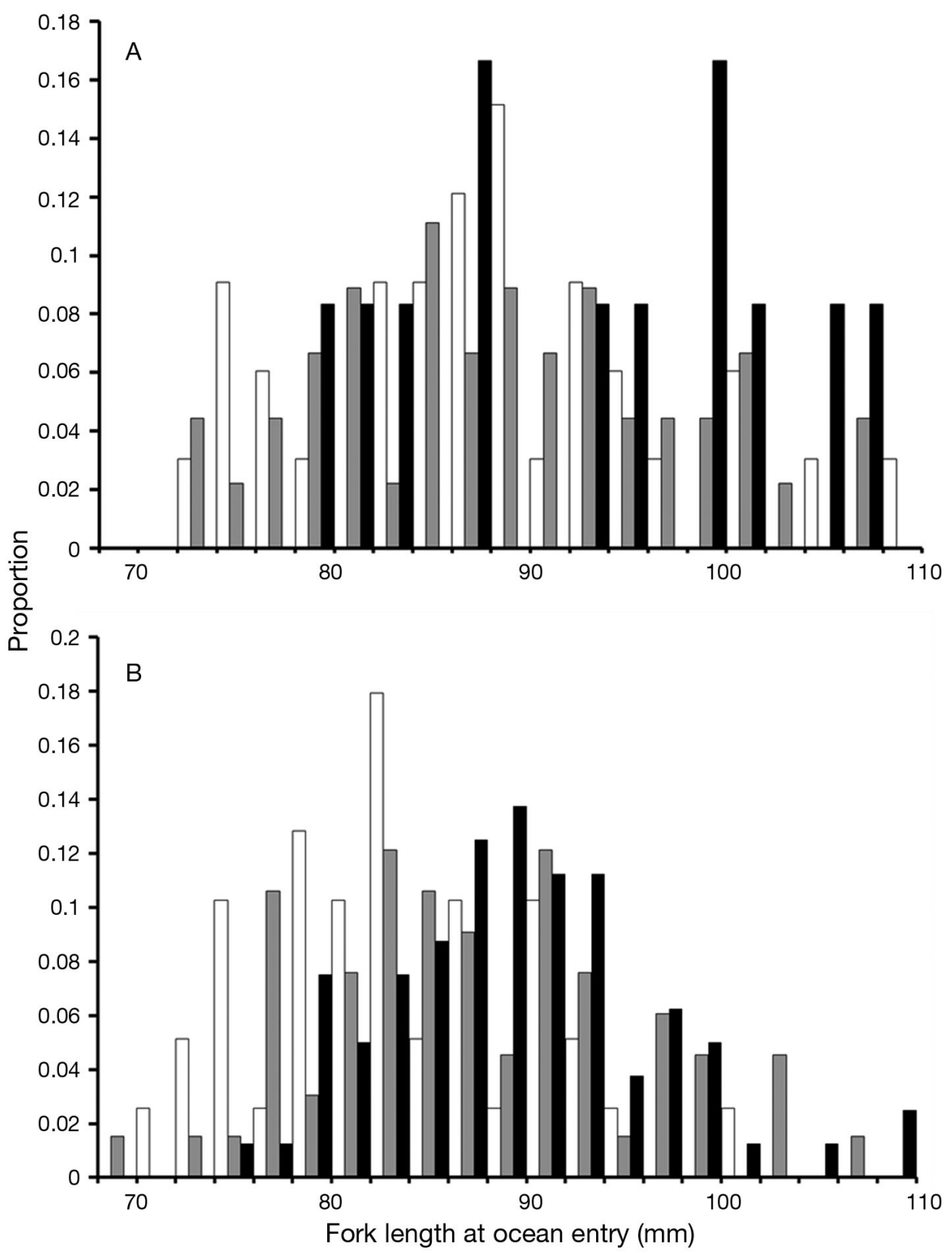

Fig. 6. Normalized fork length distributions (probability density function) at ocean entry for all 3 sample periods: estuary-exit (white), summer-ocean (grey), and fall-ocean (black). (A) There was no significant shift in size distribution in 2000 and 2001. (B) A significant shift (Wilcoxon rank sum test) was detected between estuary-exit and summer $(p=0.01)$, and estuary-exit and fall-ocean $(\mathrm{p}<0.01)$ in 2005, but not between summer- and fall-ocean in 2005

between hatchery and naturally spawned individuals from 2005. Of the fish collected during the estuaryexit period, the average measured fork length (at capture) of hatchery individuals was significantly larger $($ mean $=89.8 \mathrm{~mm}, \mathrm{SD}=14.3$ ) than the natural individuals (mean $=81.8 \mathrm{~mm}, \mathrm{SD}=10.0$ ) (ANOVA, $\mathrm{p}=0.03)$. By the fall-ocean period, hatchery individuals remained slightly larger (mean $=206.69 \mathrm{~mm}$, $\mathrm{SD}=20.6$ ) than the natural individuals (mean = $193.12 \mathrm{~mm}, \mathrm{SD}=21.6$ ) (ANOVA, $\mathrm{p}=0.02$ ).
The difference in body size between the 2 groups could relate to age differences. Specifically, hatchery fish were, on average, $20 \mathrm{~d}$ older than natural fish collected at the estuary exit. This difference in age prompted additional investigation in terms of growth rate. To examine growth rate before ocean entry, the final $50 \mathrm{~d}$ of growth before capture (last $50 \mathrm{~d}$ from edge of otolith) at the Golden Gate Bridge was compared between hatchery (mean $=0.43, \mathrm{SD}=0.16$ ) and naturally spawned (mean $=0.27, \mathrm{SD}=0.12)$ fish 

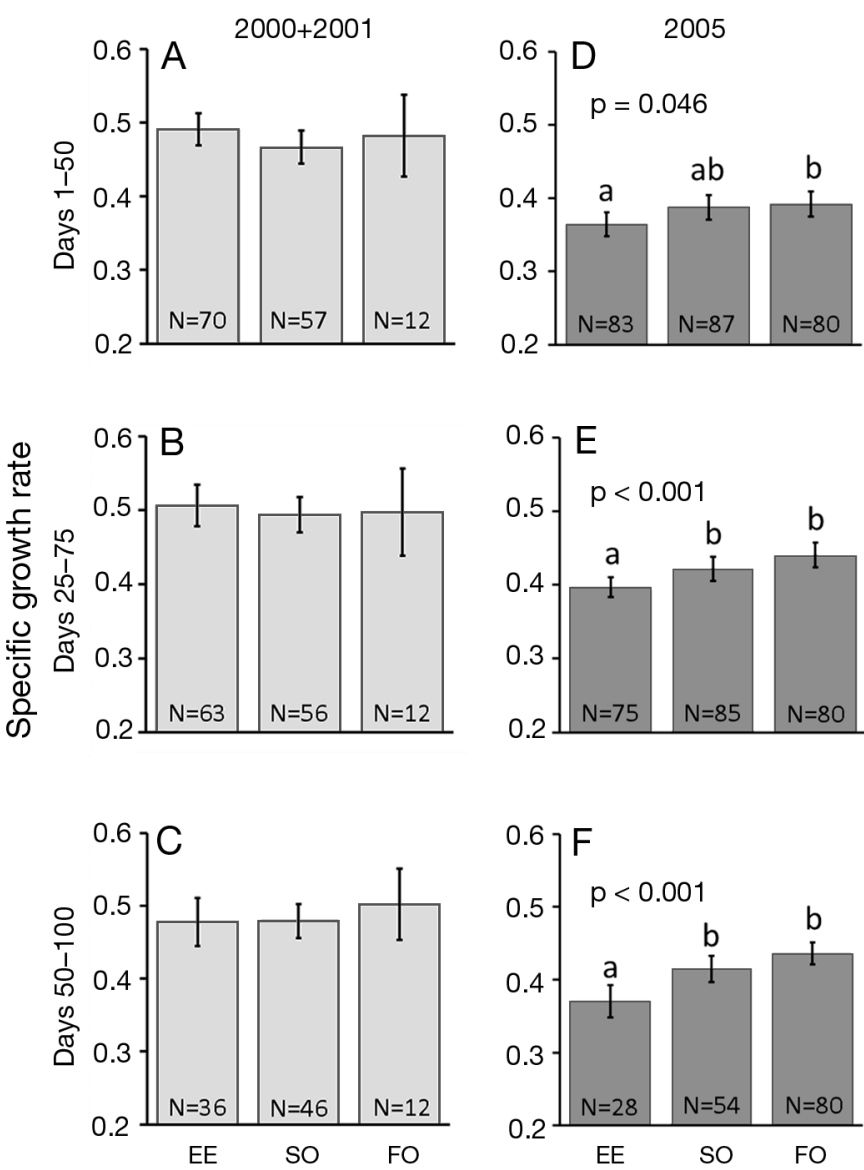

Fig. 7. Average specific growth rate over Days 1-50, 25-75, and 50-100 post exogenous feeding. (A-C) No significant differences in growth rate were observed between the sample periods (estuary-exit, EE; summer-ocean, $\mathrm{SO}$; fall-ocean, FO) in 2000 and 2001. (D-F) In 2005, significant differences were observed between estuary-exit and summer- and fallocean $(\mathrm{E}, \mathrm{F})$, but not between summer- and fall-ocean

collected during the estuary-exit sample period. Hatchery individuals had significantly faster specific growth in the $50 \mathrm{~d}$ before ocean entry (ANOVA, $\mathrm{p}=$ 0.001). Notably, it appears that in 2005 hatchery individuals had faster growth rates before ocean entry and larger size on entering the ocean than natural fish, but the proportion of hatchery to naturally spawned individuals did not change greatly during early ocean residence.

\section{DISCUSSION}

Our results show statistically significant size and growth-rate selective mortality in 2005 that was not observed in 2000 and 2001. In years of improved ocean productivity and exceptional recruitment, such as 2000 and 2001, selective mortality went undetected, as both large, fast-growing and small, slowgrowing individuals survived the ocean entry period. The selective mortality detected in 2005 is similar to cases presented by Holtby et al. (1990), Blom et al. (1994), Saloniemi et al. (2004) and Cross et al. (2008), who observed an increased benefit of larger size to other juvenile salmonids in low survival years. Poor conditions, driven by the late onset of upwelling in 2005 (Lindley et al. 2009), may have created what Cushing (1990) described in the 'match-mismatch hypothesis'. Variability in the synchronicity during the timing of emigration and food availability will drive variable survival of cohorts. Limited by food, average growth rates are lower, mortality rates are higher, and often selective mortality is evident. In 2005, the majority of juveniles entered the ocean before the onset of spring-upwelling-driven ocean productivity. This food limitation potentially led to an increase in mortality that disproportionately removed the smaller, slower-growing individuals from the population. Individuals from 2005 were significantly smaller and of significantly lower lipid content following ocean entry than individuals from 2000 and 2001 (MacFarlane 2010), which further supports food limitation and starvation as a primary mechanism driving selective mortality in 2005. However, the increase in selective mortality on smaller individuals could also be driven by increased susceptibility to predation. Regardless of the ultimate mechanism, it is clear that only the larger, faster-growing individuals survived the first month at sea in 2005 .

We also observed significant differences in average back-calculated body size at ages 60 to $110 \mathrm{~d}$, and a shift in the distribution of back-calculated body sizes at the ocean-entry benchmark in 2005. In both cases, the average back-calculated fork length of the population at estuary-exit was smaller than the backcalculated fork length of the population by summer or fall in the ocean. Only the larger individuals survived following ocean entry. No differences in backcalculated size were observed between the sample populations in summer and fall, demonstrating that the mortality occurred during the first month at sea, between the estuary-exit and summer-ocean periods. Conversely, in 2000 and 2001 we did not see evidence of significant size-selective mortality when comparing average back-calculated fork lengths. There was no significant shift in the back-calculated size distribution at ocean entry between any of the 3 sample periods in 2000 and 2001.

Many factors determine ocean-entry timing, and variation exists around the age at which fish enter 
the ocean. Ideally, an otolith mark or check formed on ocean entry could be used to provide information on age and size for each individual fish at ocean entry. However, no otolith markers have been validated for ocean entry in this system. Therefore, we applied the average age of fish caught at estuary-exit as the benchmark for when fish sampled in the summer and fall entered the ocean. This method assumes no variation in the age that fish entered the ocean. There is still the potential that back-calculated sizes could be over- or underestimated, as well as that survival may have been related to age as opposed to size. However, age and size are typically tightly coupled and difficult to separate. In our estuary-exit samples we found little variation in age (2000 and 2001 mean $=104 \mathrm{~d}, \mathrm{SD}=23 ; 2005$ mean $=93 \mathrm{~d}, \mathrm{SD}=$ 20 ) and therefore found this approach to be an adequate benchmark representing ocean entry.

In addition to size, growth-rate selective mortality was observed in 2005. Measured over 50 d intervals beginning at the exogenous feeding check, backcalculated specific growth rates were slower on average within the population at estuary-exit than within the populations that survived to summer and fall in the ocean. Individuals who were able to grow faster before ocean entry were more likely to survive to summer and fall under poor ocean conditions. The most compelling intervals were 25-75 and 50-100 d, which encompass the time period in the freshwater and estuary leading up to ocean entry.

Juvenile Central Valley Chinook salmon express a diversity of outmigration strategies that influence growth during their early life, and the habitats where they gain most of their growth are also variable. Some juveniles spend their early lives in hatcheries, others leave their natal rivers at a young age $(<1 \mathrm{mo})$ and small size $(<55 \mathrm{~mm})$ growing mainly in the Sacramento and San Joaquin river mainstems, freshwater delta or bays before they enter the ocean, while others remain for a longer period of time in their natal rivers and then migrate rapidly to sea (Williams 2012). Regardless of where fish experience faster growth and achieve larger size before ocean entry, it appears that this early growth is important for success during unproductive ocean conditions. Individuals that were small, slow growers before ocean entry did not survive when ocean conditions were not sufficient. While the major factor in the declines of the 2005 cohort was probably ocean conditions, this finding highlights the importance of freshwater restoration efforts with regards to Central Valley Chinook salmon. Therefore, for natural fish, good growth during early life stages in the fresh- water and potential access to good rearing habitats, such as floodplains or estuaries, may determine the success of a given outmigration strategy, especially in years of poor ocean conditions.

Duffy \& Beauchamp (2011) found similar results with regard to Puget Sound Chinook salmon in that growth within the sound was positively related to early marine survival. In contrast, Zabel \& Achord (2004), using mark-recapture techniques, found that downstream survival of spring and summer Chinook in the Snake River was poorly predicted by body size. However, Zabel \& Achord (2004) are keen to point out that this does not suggest that size during the freshwater phase is not important for subsequent phases, such as ocean entry or early marine residence as in our study. Using techniques consistent with ours, Tomaro et al. (2012) determined that it was not growth in freshwater, but growth after a month at sea that best predicted adult abundance. However, their samples were all collected following ocean entry, and therefore did not capture the population at the critical estuary-exit period, which we were able to achieve.

It is worth noting that fish from 2000 and 2001 had faster growth rates while in freshwater and in the estuary compared with those fish from 2005. This is surprising, as conditions in the freshwater and estuarine environments were not largely atypical in 2005 (Lindley et al. 2009). This difference in pre-ocean growth rate between the 2 years could be driven by a difference in the proportion of larger hatchery and smaller naturally spawned individuals. This remains unknown as the proportion of hatchery and natural origin fish was only measured for 2005. Another unexplored explanation for the differences in growth before ocean entry could be an increase in freshwater selective mortality in 2000 and 2001 that removed the small, slower-growing individuals before we collected them at the estuary-exit. A third scenario involves access to floodplains. Previous work has shown that access to floodplains (i.e. the Yolo Bypass) during seaward migration has a positive impact on juvenile salmon growth and survival to adulthood (Sommer et al. 2001, Jeffres et al. 2008). The Yolo Bypass floodplain was open for a greater number of days in 2000 than both 2001 and 2005 (www.water.ca.gov) giving the fish from 2000 more access to floodplain rearing. This may have been sufficient to manifest the difference in preocean growth rate seen when comparing the combined 2000 and 2001 samples to the 2005 samples.

The change in proportion of hatchery and naturally spawned individuals from estuary-exit to fall-ocean in 2005 was small and not statistically significant. 
This was surprising due to the evidence for size and growth-rate selective mortality; hatchery individuals exhibited significantly larger body sizes and faster growth before ocean entry. Previous work has shown the majority of the Chinook salmon in California's ocean fishery were of hatchery origin, and therefore we focused on a sampling design with the power to statistically detect a $>20 \%$ shift in composition between the estuary and those sampled in the fall in the ocean (Barnett-Johnson et al. 2007, Kormos et al. 2012). In addition, the high cost of sulfur analyses limited the number of samples $(\mathrm{N}=\sim 100)$ that were feasible for this study. Notably, the shift in hatchery fish composition from 60 to $67 \%$ was small enough that to deem it statistically significant $(90 \%$ power, alpha 0.05) would have required more than 2000 samples. It appears, then, that during 2005 (a year of poor ocean and salmon productivity) there was no highly favored benefit to being of hatchery or natural origin. This was surprising and prompts further investigation on additional selective factors, as our findings here suggest that hatchery individuals should have had a survival advantage in 2005 based on larger body sizes and faster growth rates.

\section{CONCLUSIONS}

We detected a significant effect of both size and growth-rate selective mortality on juvenile Central Valley fall-run Chinook salmon that appears independent of fish rearing origin. The effect was variable and only detected in a year of poor ocean conditions with low food availability and lower survival to adulthood. The mortality appeared to have occurred early in the ocean life history, predominantly between estuary-exit and the first month at sea. This significant mortality event preceded devastatingly poor adult returns in 2007, which then led to complete closures of the salmon fisheries off California in 2008 and 2009. To our knowledge, this is the first study of its kind to be done for California's Central Valley Chinook salmon, and one of the few to evaluate selective mortality over the earliest time at sea for a salmonid. We also used an innovative approach to evaluate the extent to which selective mortality acts on rearing origin. This study suggests that otoliths can be used to assess the degree of selective mortality following the critical period of ocean entry. The degree of selective mortality can then be used as an early indicator of the potential cohort success. Further work will be necessary to determine the strength and predictive ability of this indicator and the extent to which growth in specific freshwater habitats, as well as ocean drivers, affect the degree of selective mortality and survival to adulthood. Quantifying the degree of mortality could be used to direct adaptive management of remaining cohorts (i.e. 1 and $2 \mathrm{yr}$ olds) and buffering of potentially poor adult returns 2 years out.

Acknowledgements. We acknowledge the essential support of the Delta Science Fellows Program administered by California Sea Grant and funded by the Bureau of Reclamation for the Central Valley Aquatic Ecosystem Investigations as part of the California Cooperative Ecosystem Studies Unit. This publication was prepared by L.E.W. under USBR Agreement R09AC20043, California Sea Grant College Program Project R/SFBR-31. The statements, findings, conclusions, and recommendations are those of the author(s) and do not necessarily reflect the views of California Sea Grant, Bureau of Reclamation or the US Department of the Interior. We thank A. Schmitt and K. McKeegan for invaluable assistance and use of the secondary ion mass spectrometer at the University of California, Los Angeles, WM Keck Foundation Center for Isotope Geochemistry for otolith sulfur isotopic analyses, F. Loge for providing laboratory space and use of equipment at the University of California Davis, and NOAA fisheries Southwest Fisheries Science Center for additional funding. Thank you to the SWFSC Salmon Ecology team for the collection and preservation of the historical data sets. We thank C. Grimes, C. Michel, C. Phillis, and 3 anonymous reviewers whose comments greatly improved this manuscript. We are particularly grateful to P. Koch, E. Van Nieuwenhuyse, J. Hannon, and S. Oh for their support and assistance in making this project possible.

\section{LITERATURE CITED}

Anderson JT (1988) A review of size dependent survival during pre-recruit stages of fishes in relation to recruitment. J Northwest Atl Fish Sci 8:55-66

Barnett-Johnson R, Grimes CB, Royer CF, Donohoe CJ (2007) Identifying the contribution of wild and hatchery Chinook salmon (Oncorhynchus tshawytscha) to the ocean fishery using otolith microstructure as natural tags. Can J Fish Aquat Sci 64:1683-1692

Barth JA, Menge BA, Lubchenco J, Chan F and others (2007) Delayed upwelling alters nearshore coastal ocean ecosystems in the Northern California Current. Proc Natl Acad Sci USA 104:3719-3724

> Bax NJ (1983) Early marine mortality of marked juvenile chum salmon (Oncorhynchus keta) released into Hood Canal, Puget Sound, Washington, in 1980. Can J Fish Aquat Sci 40:426-435

Beamish RJ, Mahnken C (2001) A critical size and period hypothesis to explain natural regulation of salmon abundance and the linkage to climate and climate change. Prog Oceanogr 49:423-437

> Beamish RJ, Sweeting RM, Lange KL, Neville CM (2008) Changes in the population ecology of hatchery and wild coho salmon in the Strait of Georgia. Trans Am Fish Soc 137:503-520

Beamish RJ, Sweeting RM, Neville CM, Lange KL, Beacham 
TD, Preikshot D (2012) Wild Chinook salmon survive better than hatchery salmon in a period of poor production. Environ Biol Fishes 94:135-148

Bilton HT, Alderdice DF, Schnute JT (1982) Influence of time and size at release of juvenile coho salmon (Oncorhynchus kisutch) on returns at maturity. Can J Fish Aquat Sci 39:426-447

> Blom G, Svasand T, Jorstad KE, Ottera H, Paulsen OI, Holm JC (1994) Comparative survival and growth of two strains of Atlantic cod (Gadus morhua) through the earlylife stages in a marine pond. Can J Fish Aquat Sci 51: 1012-1023

Bradford MJ, Geen GH (1987) Size and growth of juvenile Chinook salmon back-calculated from otolith growth increments. In: Summerfelt RC, Hall GE (eds) Age and growth of fish. Iowa State University Press, Ames, IA, p 453-461

- Campana SE (1990) How reliable are growth back-calculations based on otoliths? Can J Fish Aquat Sci 47: 2219-2227

Campana SE, Neilson JD (1985) Microstructure of fish otoliths. Can J Fish Aquat Sci 42:1014-1032

> Claiborne AM, Fisher JP, Hayes SA, Emmett RL (2011) Size at release, size-selective mortality, and age of maturity of Willamette river hatchery yearling Chinook salmon. Trans Am Fish Soc 140:1135-1144

> Cross AD, Beauchamp DA, Myers KW, Moss JH (2008) Early marine growth of pink salmon in Prince William Sound and the coastal Gulf of Alaska during years of low and high survival. Trans Am Fish Soc 137:927-939

Crowder LB, Rice JA, Miller TJ, Marschall EA (1992) Empirical and theoretical approaches to size-based interactions and recruitment variability in fishes. In: DeAngelis DL, Gross LJ (eds) Individual-based models and approaches in ecology. Chapman and Hall, New York, NY, p 237-255

Cushing DH (1990) Plankton production and year-class strength in fish populations: an update of the match mismatch hypothesis. Adv Mar Biol 26:249-293

> Ding T, Valkiers S, Kipphardt H, De Bievre P, Taylor PDP, Gonfiantini R, Krouse R (2001) Calibrated sulfur isotope abundance ratios of three IAEA sulfur isotope reference materials and V-CDT with a reassessment of the atomic weight of sulfur. Geochim Cosmochim Acta 65: 2433-2437

> Duffy EJ, Beauchamp DA (2011) Rapid growth in the early marine period improves the marine survival of Chinook salmon (Oncorhynchus tshawytscha) in Puget Sound, Washington. Can J Fish Aquat Sci 68:232-240

Durazo R, Baumgartner TR, Bograd SJ, Collins CA and others (2001) The state of the California Current, 2000-2001: a third straight La Niña year. Calif Coop Ocean Fish Invest Rep 42:29-60

Fisher FW (1994) Past and present status of Central Valley Chinook salmon. Conserv Biol 8:870-873

> Fritts AL, Scott JL, Pearsons TN (2007) The effects of domestication on the relative vulnerability of hatchery and wild origin spring Chinook salmon (Oncorhynchus tshawytscha) to predation. Can J Fish Aquat Sci 64:813-818

> Good SP, Dodson JJ, Meekan MG, Ryan DAJ (2001) Annual variation in size-selective mortality of Atlantic salmon (Salmo salar) fry. Can J Fish Aquat Sci 58:1187-1195

Grimes CB, Isely JJ (1996) Influence of size-selective mortality on growth of gulf menhaden and king mackerel larvae. Trans Am Fish Soc 125:741-752
Gulland JA (1965) Survival of the youngest stages of fish, and its relation to year-class strength. Int Comm Northwest Atl Fish Spec Pub 6:363-372

Healey MC (1982) Timing and relative intensity of sizeselective mortality of juvenile chum salmon (Oncorhynchus keta) during early sea life. Can J Fish Aquat Sci 39: 952-957

Hjort J (1914) Fluctuations in the great fisheries of Northern Europe. Rapp P-V Réun Cons Int Explor Mer 20:1-228

> Holtby LB, Andersen BC, Kadowaki RK (1990) Importance of smolt size and early ocean growth to interannual variability in marine survival of coho salmon (Oncorhynchus kisutch). Can J Fish Aquat Sci 47:2181-2194

Houde ED (1987) Fish early life dynamics and recruitment variability. Am Fish Soc Symp 2:17-29

Jeffres C, Opperman JJ, Moyle PB (2008) Ephemeral floodplain habitats provide best growth conditions for juvenile Chinook salmon in a California river. Environ Biol Fishes 83:449-458

Johnson RC, Weber PK, Wikert JD, Workman ML, MacFarlane RB, Grove MJ, Schmitt AK (2012) Managed metapopulations: Do salmon hatchery 'sources' lead to in-river 'sinks' in conservation? PLoS ONE 7:e28880

Kormos B, Palmer-Zwahlen M, Low A (2012) Recovery of coded-wire tags from Chinook salmon in California's Central Valley escapement and ocean harvest in 2010. Fisheries Branch Administrative Report 2012-02, California Department of Fish and Game, Sacramento, CA

Laplace PS (1812) Theorie analytique des probabilities. Courcier, Paris

Levin PS, Zabel RW, Williams JG (2001) The road to extinction is paved with good intentions: negative association of fish hatcheries with threatened salmon. Proc R Soc Lond B Biol Sci 268:1153-1158

Lewis JR, Sauro J (2006) When 100\% really isn't 100\%: improving the accuracy of small-sample estimates of completion rates. J Usability Stud 1:136-150

Lindley ST, Grimes CB, Mohr MS, Peterson WT and others (2009) What caused the Sacramento River fall Chinook stock collapse? NOAA Tech Memo, NMFS-SWFSC-447, Seattle, WA

> MacFarlane RB (2010) Energy dynamics and growth of Chinook salmon (Oncorhynchus tshawytscha) from the Central Valley of California during the estuarine phase and first ocean year. Can J Fish Aquat Sci 67:1549-1565

MacFarlane RB, Norton EC (2002) Physiological ecology of juvenile Chinook salmon (Oncorhynchus tshawytscha) at the southern end of their distribution, the San Francisco Estuary and Gulf of the Farallones, California. Fish Bull 100:244-257

> MacFarlane RB, Ralston S, Royer C, Norton EC (2005) Juvenile Chinook salmon (Oncorhynchus tshawytscha) growth on the central California coast during the $1998 \mathrm{El}$ Niño and 1999 La Niña. Fish Oceanogr 14:321-332

> Marshall SL, Parker SS (1982) Pattern identification in the microstructure of sockeye salmon (Oncorhynchus nerka) otoliths. Can J Fish Aquat Sci 39:542-547

> Miller TJ, Crowder LB, Rice JA, Marschall EA (1988) Larval size and recruitment mechanisms in fishes: toward a conceptual framework. Can J Fish Aquat Sci 45:1657-1670

> Neilson JD, Geen GH (1982) Otoliths of Chinook salmon (Oncorhynchus tshawytscha): daily growth increments and factors influencing their production. Can J Fish Aquat Sci 39:1340-1347

> Neilson JD, Geen GH (1986) First-year growth rate of Sixes 
River Chinook salmon as inferred from otoliths: effects on mortality and age at maturity. Trans Am Fish Soc 115: 28-33

Pacific Fisheries Management Council (PFMC) (2013) Preseason Report I: Stock Abundance Analysis and Environmental Assessment Part 1 for 2013 Ocean Salmon Fishery Regulations. PFMC, Portland, OR

Parker RR (1968) Marine mortality schedules of pink salmon of Bella Coola River, central British Columbia. J Fish Res Board Can 25:757-794

Parker RR (1971) Size selective predation among juvenile salmonid fishes in a British Columbia inlet. J Fish Res Board Can 28:1503-1510

Pearcy WG (1992) Ocean ecology of North Pacific salmonids. University of Washington Press, Seattle, WA

Peterson B, Emmett R, Goericke R, Venrick E and others (2006) The state of the California Current, 2005-2006: warm in the north, cool in the south. Calif Coop Ocean Fish Invest Rep 47:30-74

Reinhardt UG, Yamamoto T, Nakano S (2001) Effects of body size and predators on intracohort competition in wild and domesticated juvenile salmon in a stream. Ecol Res 16:327-334

Ruggerone GT, Peterman RM, Dorner B, Myers KW (2010) Magnitude and trends in abundance of hatchery and wild pink salmon, chum salmon, and sockeye salmon in the North Pacific Ocean. Mar Coast Fish 2:306-328

Saloniemi I, Jokikokko E, Kallio-Nyberg I, Jutila E, Pasanen P (2004) Survival of reared and wild Atlantic salmon smolts: size matters more in bad years. ICES J Mar Sci 61:782-787

Schwing FB, Bograd SJ, Collins CA, Gaxiola-Castro G and others (2002) The state of the California Current, 20012002: Will the California Current system keep its cool, or is El Niño looming? Calif Coop Ocean Fish Invest Rep 43: 31-68

Schwing FB, Bond NA, Bograd SJ, Mitchell T, Alexander MA, Mantua N (2006) Delayed coastal upwelling along the US West Coast in 2005: a historical perspective. Geophys Res Lett 33:L22SO1, doi:10.1029/2006GL026911

Shepherd JG, Cushing DH (1980) A mechanism for density-

Editorial responsibility: Nicholas Tolimieri, Seattle, Washington, USA dependent survival of larval fish as the basis of a stockrecruitment relationship. J Cons 39:160-167

Sogard SM (1997) Size-selective mortality in the juvenile stage of teleost fishes: a review. Bull Mar Sci 60: 1129-1157

Sommer TR, Nobriga ML, Harrell WC, Batham W, Kimmerer WJ (2001) Floodplain rearing of juvenile Chinook salmon: evidence of enhanced growth and survival. Can J Fish Aquat Sci 58:325-333

Titus RG, Volkoff MC, Snider WM (2004) Use of otolith microstructure to estimate growth rates of juvenile Chinook salmon from a Central Valley, California stock. Am Fish Soc Symp 39:181-202

Tomaro LM, Teel DJ, Peterson WT, Miller JA (2012) When is bigger better? Early marine residence of middle and upper Columbia River spring Chinook salmon. Mar Ecol Prog Ser 452:237-252

> Unwin MJ (1997) Fry-to-adult survival of natural and hatchery-produced Chinook salmon (Oncorhynchus tshawytscha) from a common origin. Can J Fish Aquat Sci 54: 1246-1254

- Ward BR, Slaney PA, Facchin AR, Land RW (1989) Sizebiased survival in steelhead trout (Oncorhynchus mykiss): back-calculated lengths from adults' scales compared to migrating smolts at the Keogh River, British Columbia. Can J Fish Aquat Sci 46:1853-1858

- Weber PK, Hutcheon ID, McKeegan KD, Ingram BL (2002) Otolith sulfur isotope method to reconstruct salmon (Oncorhynchus tshawytscha) life history. Can J Fish Aquat Sci 59:587-591

- Wells BK, Santora JA, Field JC, MacFarlane RB, Marinovic BB, Sydeman WJ (2012) Population dynamics of Chinook salmon Oncorhynchus tshawytscha relative to prey availability in the central California coastal region. Mar Ecol Prog Ser 457:125-137

Williams JG (2012) Juvenile Chinook salmon (Oncorhynchus tshawytscha) in and around the San Francisco estuary. San Francisco Est Watershed Sci 10:1-24

Zabel RW, Achord S (2004) Relating size of juveniles to survival within and among populations of Chinook salmon. Ecology 85:795-806

Submitted: September 7, 2012; Accepted: March 25, 2013 Proofs received from author(s): July 10, 2013 